\title{
Assessment of the MRI and Behavioral Test Results in a Focal Cerebral Ischemia-Reperfusion Model in the Rat after Separate and Combined Use of Mouse-Derived Neural Progenitor Cells, Human-Derived Neural Progenitor Cells and Atorvastatin
}

\author{
Alican TAHTA ${ }^{1}$, Nail IZGI ${ }^{2}$, Tugba BAGCI-ONDER ${ }^{3}$, Ece ERDAG ${ }^{4}$, Yavuz ARAS ${ }^{2}$, Cetin GENC ${ }^{2}$ \\ ${ }^{1}$ Medipol University Hospital, Department of Neurosurgery, Istanbul, Turkey \\ ${ }^{2}$ Istanbul University, Istanbul School of Medicine, Department of Neurosurgery, Istanbul, Turkey \\ ${ }^{3}$ Koc University, School of Medicine, Brain Cancer Research and Therapy Laboratory, Istanbul, Turkey \\ ${ }^{4}$ University of Maastricht, Faculty of Neuroscience, Maastricht, Netherlands \\ This study has been presented in the $30^{\text {rd }}$ Scientific Meeting of Turkish Neurosurgical Society at Antalya, Turkey
}

\section{ABSTRACT}

AIM: To assess the efficacy of Neural progenitor cell (NPC) transplantation in ischemic stroke, and to investigate whether atorvastatin enhances therapeutic potency of NPC after stroke.

MATERIAL and METHODS: The focal cerebral ischemia-reperfusion model was performed by transient occlusion of middle cerebral artery. Rats were assigned randomly to receive intracerebral transplantation of mouse NPC alone (mNPC), human NPC alone (hNPC), mouse NPC plus oral atorvastatin (mNPC+A), human NPC plus oral atorvastatin (hNPC+A), oral atorvastatin alone, or intracerebral Dulbecco's Modified Eagle's medium injection (control group). Adhesive removal, rotarod, cylinder tests, and magnetic resonance imaging (MRI) were used for assessment of rats during 4 weeks. After sacrification on $28^{\text {th }}$ day, rats were investigated by immunofluorescent staining.

RESULTS: The hNPC and mNPC groups showed significantly improved functional outcome and reduced infarct area ratio compared with the control group. The hNPC group had significantly better performance and lower infarct area ratio than the mNPC group. Addition of atorvastatin to stem cell therapy significantly improved functional outcome, although it did not affect the infarct area ratio on MRI. Anti-inflammatory response in the infarct area was higher in the mNPC group. NPC transplantation significantly reduced the amount of microglia and a significant increase in the amount of astrocytes. CD8a+ T lymphocyte and granzyme B activities were not detected in any of the subjects.

CONCLUSION: Both hNPC and mNPC treatments significantly improved functional outcome, and reduced infarct area ratio after stroke. Atorvastatin enhanced the therapeutic potency of NPCs, including neurological improvement.

KEYWORDS: Atorvastatin, Focal cerebral ischemia, Human derived neural progenitor cell, Mouse derived neural progenitor cell, Neural progenitor cell, Rats 


\section{- INTRODUCTION}

I schemic stroke is caused by interruption of blood flow that leads to ischemic changes in brain. It is one of the leading causes of mortality and morbidity worldwide. The majority of stroke patients suffer from progression of the ischemic area causing debilitating neurological deficits, and it creates a great problem for the population (18).

The brain has the potential to resolve stroke-related functional deficits via activation of alternative neuronal networks, rewiring new circuits, plastic re-organizations, and tissue repair by endogenous stem cells. Unfortunately, these are not fully understood and are not sufficient to compensate the damage caused by stroke (11).

Despite the advances in recanalization techniques, stroke prevention and extensive animal and clinical researches, no neuroprotective agent has been demonstrated to be effective in repairing brain damage following stroke $(1,6)$. However, neural progenitor cells (NPCs) are noted to be promising therapeutic candidates for stroke. It has been shown that NPCs could integrate in the ischemic brain, influence the neural niches, exert immunomodulatory actions and reduce the damage in the ischemic area in the brain (6). However, NPC's therapeutical potential is hindered by the low survival of these cells due to their precarious surroundings.

Early administration of 3-hydroxy-3-methylglutaryl coenzyme$A$ reductase inhibitors (statins) reduces the infarct volume in experimental acute stroke models $(8,10)$. Rats treated with atorvastatin 24 hours after focal ischemia have enhanced neurological function, angiogenesis, and synaptogenesis in the infarct region (7).

In our study, we aimed to improve the environment of NPCs and protect the brain from ischemic and reperfusion injuries with the help of atorvastatin treatment.

\section{MATERIAL and METHODS}

All experimental procedures were approved by the Experimental Animals Committee of Istanbul University (2014/61). Forty-eight male Sprague-Dawley rats weighing 270-300 g were used in this study. The rats were kept on a 12-h light/dark cycle with access to food and water ad libitum.

\section{Focal Cerebral Ischemia Model and Cell Transplantation}

After the rats had been anesthetized with 1\% ketamine (30 $\mathrm{mg} / \mathrm{kg}$, intraperitoneal), and xylazine hydrochloride $(4 \mathrm{mg} / \mathrm{kg}$, intraperitoneal), we maintained the rats' body temperatures at $37 \pm 1^{\circ} \mathrm{C}$ using a rectal probe and a heating pad. Focal cerebral ischemia was induced by occlusion of left middle cerebral artery for 90 minutes, using the method of Uluc et al. A $3.0 \mathrm{~cm}$ length of 4-0 monofilament nylon suture with a silicon-coated tip (Doccol Corp., Redlands, CA, USA) was inserted into the left common carotid artery lumen through the external carotid artery. The suture was gently advanced into the internal carotid artery until it blocked the bifurcation of the middle cerebral artery. Ninety minutes after occlusion, the animals were re-anesthetized and reperfused by withdrawing the suture (35-37). To avoid an immune response to the transplanted cells, all rats received cyclosporine A $(10 \mathrm{mg} / \mathrm{kg} /$ day, intraperitoneal) (Novartis, Switzerland) starting from 1 day before the transplantation.

Rats were assigned randomly to the following 6 groups; (1) intracerebral Dulbecco's Modified Eagle's Medium (DMEM) (Sigma Aldrich, MO, USA) injection (control group $\mathrm{n}=8$ ); (2) intracerebral DMEM injection and oral atorvastatin treatment (atorvastatin group $\mathrm{n}=8$ ); (3) $\mathrm{h}-\mathrm{NPC}$ transplantation (hNPC group $n=8$ ); (4) m-NPC transplantation (mNPC group $n=8$ ); (5) h-NPC transplantation and oral atorvastatin treatment (hNPC+A n=8); (6) m-NPC transplantation and oral atorvastatin treatment $(\mathrm{mNPC}+\mathrm{A} n=8)$.

Twenty-four hours after focal cerebral ischemia, 600,000 NPCs in a total volume of $8 \mu \mathrm{l}$ or $8 \mu \mathrm{l}$ DMEM were transplanted into the two different locations in the ipsilateral striatum region using the following stereotaxic coordinates for the corresponding groups: (1) $+0.5 \mathrm{~mm}$ anteroposterior, $+3 \mathrm{~mm}$ mediolateral and +5 mm dorsoventrally; (2) $-0.5 \mathrm{~mm}$ anteroposterior, $+3 \mathrm{~mm}$ mediolateral, $+5 \mathrm{~mm}$ dorsoventrally (Figure $1 \mathrm{~A}$ ). All cells were infused at a rate of $1 \mu \mathrm{l} / \mathrm{min}$ to prevent cellular aggregation. $A$ 26-gauge Hamilton syringe (Reno, NV, USA) was left in place for an additional 5 minutes to stabilize the transplanted cells (Figure 1B, C).

mNPCs (C17.2-07062902, Sigma Aldrich, MO, USA) isolated from the neonatal mice cerebellum, and hNPCs (ENStem-A SCR055, Millipore, MA, USA) derived from embryonal stem cells were commercially purchased. Cell culture procedures were held at the Stem Cell Laboratory, Faculty of Medicine, Koc University. Cells were kept in liquid nitrogen and used after dissolving when necessary.

Frozen cells in liquid nitrogen were dissolved in a water bath at $37{ }^{\circ} \mathrm{C}$. They were transferred into $15 \mathrm{ml}$ tubes with $5 \mathrm{ml}$ DMEM. Tubes were centrifuged for 5 minutes at $1500 \mathrm{rpm}$. The supernatant was discarded.

hNPCs were grown in DMEM supplemented with $10 \%$ fetal bovine serum (FBS) and 1\% penicillin/streptomycin. mNPCs were grown in NeuroCult NS-A Basal neural stem cell medium (Stem Cell Technologies, Canada) supplemented with NeuroCult NS-A Proliferation Supplements (\#05751, Stem Cell Technologies, Canada), 20 ng/ml EGF (\#02633, Stem Cell Technologies, Canada), 20 ng/ml FGF (\#02634, Stem Cell Technologies, Canada), $2 \mathrm{~g} / \mathrm{ml}$ heparin (\#07980, Stem Cell Technologies, Canada), and 1\% penicillin/streptomycin.

hNPCs were transferred into another glass container by passaging after approximately $70-80 \%$ coating of the surface of the glass container. Stem cell medium on the cells was removed. The glass container was washed with sterile phosphate-buffered saline. Trypsin/EDTA preheated to $37^{\circ} \mathrm{C}$ was added to glass containers $\left(0.5 \mathrm{ml}\right.$ for $25 \mathrm{~cm}^{2}, 1 \mathrm{ml}$ for $75 \mathrm{~m}^{2}$ ). Five $\mathrm{ml}$ FBS containing growth medium was added to inactivate trypsin after 3-4 minutes of incubation. Cells were counted and cultivated on another glass container. The medium of the cells was replaced with new growth medium once every three days. 
mNPCs were passaged after reaching a certain size due to their spherical growth patterns without attaching to the base of the glass container. The medium and cells were collected and centrifuged at $1200 \mathrm{rpm}$. The supernatant was discarded, and the pellet suspended and cultivated on glass containers.

\section{Behavioral Tests}

Behavioral tests were performed before, and 1 to 28 days after focal cerebral ischemia. The adhesive removal test was conducted to evaluate sensorimotor deficits of the rats. Small adhesive tapes $\left(113 \mathrm{~mm}^{2}\right)$ were simultaneously placed on both dorsal forepaws of animals and the difference of timeto-remove from the left and right forepaws for each rat was recorded (16).

In the rotarod test, the rod speed increased from 4 to $40 \mathrm{rpm}$ in 5 minutes. All rats were placed on the rotarod cylinder, and the time that each rat stayed on the cylinder was recorded for three trials. We calculated the average time (in seconds) for three trials and divided it by 100 seconds which was the baseline level recorded in observations before focal cerebral ischemia (30).

The cylinder test was used to evaluate locomotor asymmetry after focal cerebral ischemia. The animals were placed in an open-top, transparent glass cylinder $(20 \mathrm{~cm}$ diameter and 30 $\mathrm{cm}$ height), and forelimb activity while rearing against the wall of cylinder was recorded. Forelimb use was defined by the placement of the whole palm on the cylinder that indicates its use for body support. Forelimb contacts were scored for each side for 10 minutes. Overall limb use asymmetry score calculated by subtracting the percent of impaired forelimb use from the percent of nonimpaired forelimb use (28).

\section{MRI and Lesion Volume Analysis}

Experiments were conducted on a $3 T$ MRI (Magnetom Spectra, Siemens Healthcare GmbH, Germany). T2-weighted images were acquired at 1 and 28 days after focal cerebral ischemia. The following parameters were used fpr MRI: echo time (TE) $85 \mathrm{~ms}$, repetition time (TR) $3000 \mathrm{~ms}, 8$ coronal slices, slice thickness $0.8 \mathrm{~mm}$, and gap $0.2 \mathrm{~mm}$. Lesion areas were determined by a blinded investigator with the image processing software, OsiriX (Pixmeo, Bernex, Switzerland). The edge of the cerebral ischemic area was traced manually on each of the 8 coronal slices, and average corrected hemispheric lesion area was calculated in OsiriX. The corrected hemispheric lesion area (HLA) was calculated with the equation:

$$
\text { HLA (\%) }=((\text { LT- }(\mathrm{RT}-\mathrm{RI})) / \mathrm{LT} \times 100
$$

where $L T$ is the area of the left hemisphere (in $\mathrm{mm}^{2}$ ), $R T$ is the area of the right hemisphere (in $\mathrm{mm}^{2}$ ), and Rl is the infarct area (in $\mathrm{mm}^{2}$ ).

With this correction procedure, the effects of tissue shrinkage (due to histological fixation) as well as edema formation on the estimation of infarct size were minimized (22).

\section{Immunohistochemical Analysis}

Animals were anesthetized with intraperitoneal administration of $30 \mathrm{mg} / \mathrm{kg}$ ketamine and $10 \mathrm{mg} / \mathrm{kg}$ xylazine hydrochloride 28 days after focal cerebral ischemia. After cranial MRIs were obtained, transcardiac perfusion fixation was achieved by isotonic solution and $4 \%$ paraformaldehyde. The cerebrum was carefully taken out after removal of the calvarium, and kept in $4 \%$ paraformaldehyde overnight. Then, $40 \mu \mathrm{m}$-thick sections were taken from infarct area after embedding in paraffin.

The preparations were examined under a confocal microscope (TCS SP8, Leica, IL, USA) by two different observers. Preparations were scored as '(-) no staining, (+) very little staining, $(++)$ less staining, $(+++)$ staining, $(++++)$ more staining' according to the antibody binding degree. The score was determined by the joint decision of two different observers.

\section{CD5}

Fluorescein isothiocyanate (FITC) conjugated antiCD5 monoclonal antibody (OX-19, ab24500, Abcam, UK) was used to assess the efficacy of $T$ lymphocytes.
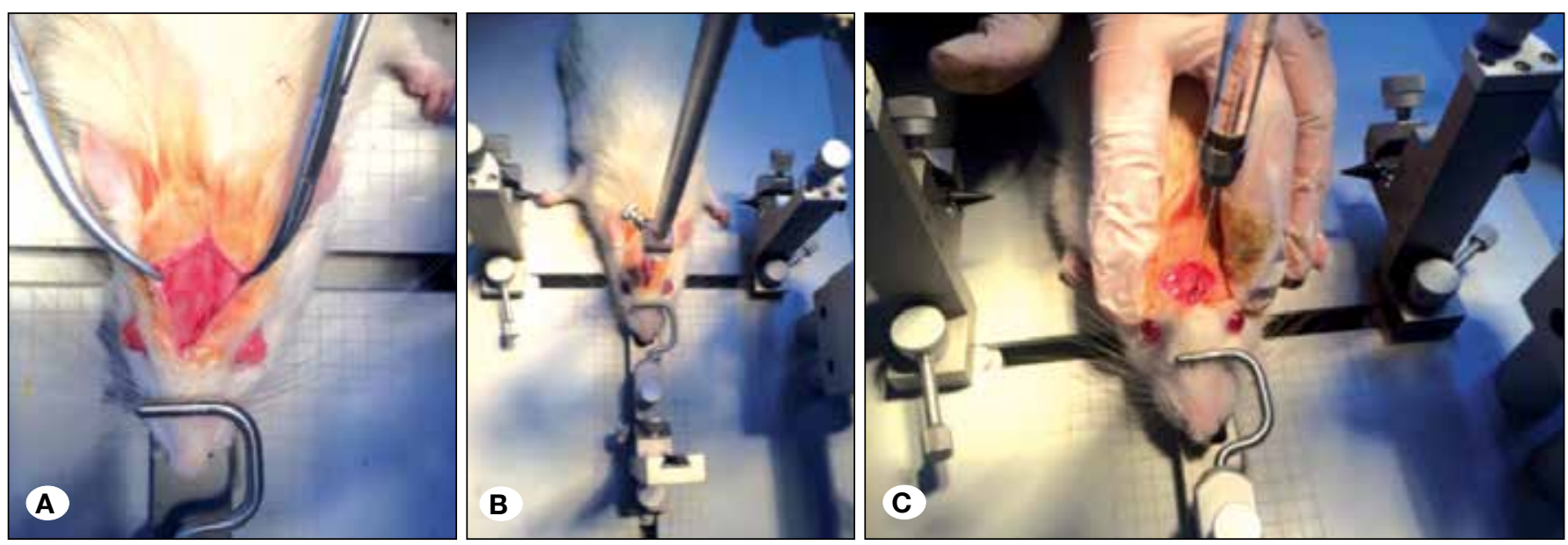

Figure 1: Revealing of Bregma (A), Determination of coordinates with stereotaxic device (B), Stem cell administration with Hamilton syringe (C). 
Tahta A. et al: Cerebral Ischemia-Reperfusion in Rats

The reactions of antibodies with rat tissues were considered. Secondary antibody was not used due to selection of FITC antibody. The two-day staining procedure was performed. Stained sections were maintained at $+4{ }^{\circ} \mathrm{C}$ in a dark room after dropping Dako fluorescent solution.

Two different diluted solutions (1/100 and 1/200) were evaluated to determine the appropriate dilution for antibody reaction. After taking into consideration of intensive binding in the $1 / 100$ dilution, we decided to use the 1/200 dilution. Antibodies were diluted in PBS containing $1 \%$ goat serum. $100 \mu$ l solution was used per slice.

On the $1^{\text {st }}$ day; the sections were deparaffinized at $65^{\circ} \mathrm{C}$ in the incubator for 15-20 minutes. They were soaked in xylene for 2 minutes (this procedure was repeated twice). Sections were washed two times for 5 minutes in respectively $100 \%, 90 \%$, and $70 \%$ ethanol series. Then, the sections were blocked with $5 \%$ goat serum containing PBS at room temperature for 20 minutes. Excess fluid around the sections was absorbed by filter paper, and the borders of the sections were marked using a hydrophobic pen. The antibody dilution was prepared in accordance with the instructions. Sections were incubated at $+4^{\circ} \mathrm{C}$ overnight. On the $2^{\text {nd }}$ day, sections were washed three times with PBS for 1 minute in order to remove unbound antibodies, and the closure solution was then dropped and sections were examined under the fluorescent microscope.

\section{CD11b, Glial Fibrillary Acidic Protein (GFAP), CD8a and Granzyme B}

Anti-CD11b rabbit polyclonal antibody (ab75476, Abcam, UK) was used as the primary antibody to determine microglia function in stroke and the stem cell effect on microglia. We decided to use the $1 / 400$ dilution rate after optimization studies. Horse radish peroxidase (HRP) conjugated goat antirabbit immunoglobulin G (lgG) (Alexa Fluor 405, ab175652, UK) at $1 / 400$ dilution was used as the secondary antibody.

Anti-GFAP (ab7260, Abcam, UK) is used in neurological disorders as an astroglial biomarker. We used anti-GFAP to evaluate the transformation of stem cells into glial cells in our study. The primary antibody was prepared in 1/1000 dilution with $1 \%$ goat serum containing PBS. Goat anti-rabbit lgG H\&L (Alexa Fluor 594, ab150080, Abcam, UK) was selected as the secondary antibody and a 1/400 dilution was prepared.

Anti-Granzyme B (ab53097, Abcam, UK) and anti-CD8a (ab33786, Abcam, UK) were used as primary antibodies to determine the effect of stem cells on CTLs in the ischemic brain. Goat anti-rabbit IgG H\&L (Alexa Fluor 405, ab175652, Abcam, UK) was used as the secondary antibody. 1/100 dilution for primary antibody and 1/400 dilution for secondary antibody were used.

On the $1^{\text {st }}$ day; sections were deparaffinized at $65^{\circ} \mathrm{C}$ in the incubator for 15-20 minutes. They were soaked in xylene for 2 minutes (this procedure was repeated twice). The sections were washed two times for 5 minutes in respectively $100 \%$, $90 \%$, and $70 \%$ ethanol series. Then, the sections were blocked with $5 \%$ goat serum containing PBS at room temperature for 20 minutes. Excess fluid around the sections was absorbed by filter paper, and the borders of sections were marked with a hydrophobic pen. The antibody dilution was prepared in accordance with the instructions. The sections were incubated at $+4^{\circ} \mathrm{C}$ overnight. On the $2^{\text {nd }}$ day, sections were washed three times with PBS for 1 minute in order to remove unbound antibodies. The secondary antibody was diluted in $1 \%$ goat serum containing PBS solution, and incubated for two hours at room temperature in the dark. Sections were washed three times for one minute with PBS in order to remove unbound secondary antibodies. Closure solution was dropped and sections were examined under a fluorescent microscope.

\section{Statistical Analysis}

Statistical analysis was performed with SPSS V22 (SPSS Inc, IL, USA). All values were expressed as mean \pm SEM. Statistical comparisons of lesion areas on MRI were performed using the Kruskal-Wallis ANOVA test. Behavioral tests were performed using ANOVAand immunofluorescent staining evaluation was performed using the Fisher test. A probability $(p)$ value of $<0.05$ was considered significant.

\section{RESULTS}

\section{MRI}

There was no significant difference between the groups on the $1^{\text {st }}$ day. The infarct area of the hNPC+A group was the smallest among the 6 groups. On the $28^{\text {th }}$ day, there was a significant difference between the control group and the mNPC and hNPC groups. The hNPC group had a smaller infarct area compared with the mNPC group. Addition of atorvastatin to the NPC treatment had no effect on reducing the infarct area (Table I, Figures 2, 3).

\section{Behavioral Tests}

To determine whether the transplanted hNPCs, mNPCs, and addition of atorvastatin treatment to stem cell transplantation can improve sensorimotor and locomotor deficits, behavior tests were compared. Prior to focal cerebral ischemia, the neurological scores were similar among all animals. One day after the ischemia model but prior to the intracerebral injections, there was no statistical difference in adhesive removal, rotarod, and cylinder tests among all groups. The overall effects of mNPC and hNPC transplantation on functional recovery were significant for adhesive removal, rotarod, and cylinder tests compared with DMEM injection (control). Addition of oral atorvastatin to mNPC or hNPC transplantation showed improvement in behavioral tests; however, there was no statistical significance.

The adhesive removal test began to show improvement from the $7^{\text {th }}$ day, and the effect persisted until the end of the study in the mNPC, hNPC, mNPC+A, and hNPC+A groups $(p<0.0001)$. The hNPC group showed significantly better performance than the mNPC group during the study period $(p<0.0001)$. On the $14^{\text {th }}$ day, the mNPC group showed better performance than the mNPC+A group, and also the hNPC group showed better performance than the hNPC+A group $(p<0.0001)$. On the last day of the study, the mNPC and hNPC groups' scores were better than the control group $(p<0.0001)$. 
Also, treatment with hNPC significantly improved functional recovery compared with mNPC. Rats treated with $\mathrm{mNPC}$ and oral atorvastatin showed a significant reduction in adhesive removal time compared with rats treated with only mNPC (Table II, Figure 4).
hNPC transplantation to the rats improved functional recovery in the rotarod test from day 7 through 28 , compared with DMEM injection (control), and mNPC transplantation. Rats that received $\mathrm{mNPC}$ and oral atorvastatin showed significantly better results compared with rats treated with MNPC only on the $14^{\text {th }}$ day. Rats treated with hNPC and oral atorvastatin

Table I: Infarct Area Ratios on MRI (\%)

\begin{tabular}{|c|c|c|c|c|c|c|}
\hline & $\begin{array}{c}\text { Control } \\
(n=8)\end{array}$ & $\begin{array}{l}\text { Atorvastatin } \\
\qquad(\mathrm{n}=8)\end{array}$ & $\begin{array}{c}\text { mNPC } \\
(n=8)\end{array}$ & $\begin{array}{c}\mathrm{mNPC}+\mathrm{A} \\
(\mathrm{n}=8)\end{array}$ & $\begin{array}{c}\text { hNPC } \\
(n=8)\end{array}$ & $\begin{array}{c}\mathrm{hNPC}+\mathrm{A} \\
(\mathrm{n}=8)\end{array}$ \\
\hline $1^{\text {st }}$ Day & $32.38+4.71$ & $34.13+4.26$ & $32.13 \pm 3.52$ & $30.50 \pm 3.12$ & $33+4.38$ & $34.25 \pm 4.77$ \\
\hline Mean \pm SE Median & 32 & 34 & 32 & 31 & 32 & 32.5 \\
\hline $28^{\text {th }}$ Day & $26.75 \pm 3.33$ & $25 \pm 3.66$ & $13.75 \pm 2.96$ & $10.25+2.19$ & $7.63 \pm 1.60$ & $6.25 \pm 3.84$ \\
\hline Mean \pm SE Median & $2 \overline{7}$ & $\overline{24} .5$ & 13.5 & $9 . \overline{5}$ & $\overline{8}$ & 4.5 \\
\hline
\end{tabular}

SE: Standard error.

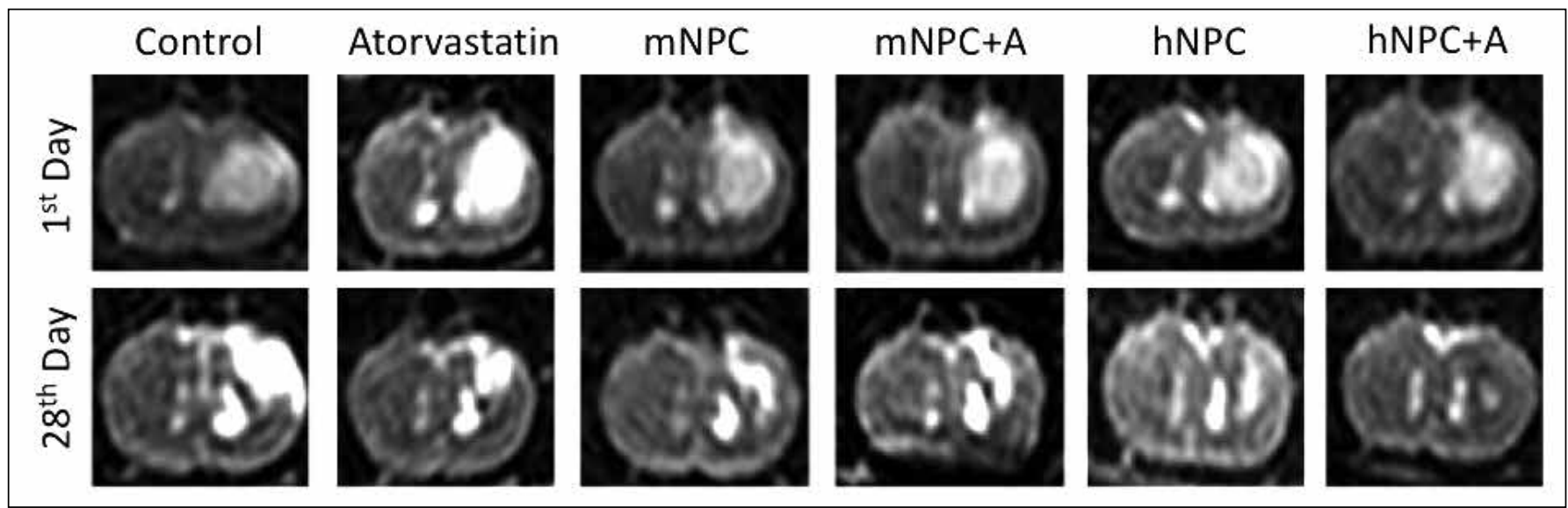

Figure 2: T2-weighted cranial MR images obtained on days 1 and 28 from the subjects. (mNPC: Mouse Neural Progenitor Cell, mNPC+A: Mouse Neural Progenitor Cell and oral atorvastatin treatment, hNPC: Human Neural Progenitor Cell, hNPC+A: Human Neural Progenitor Cell and oral atorvastatin treatment).

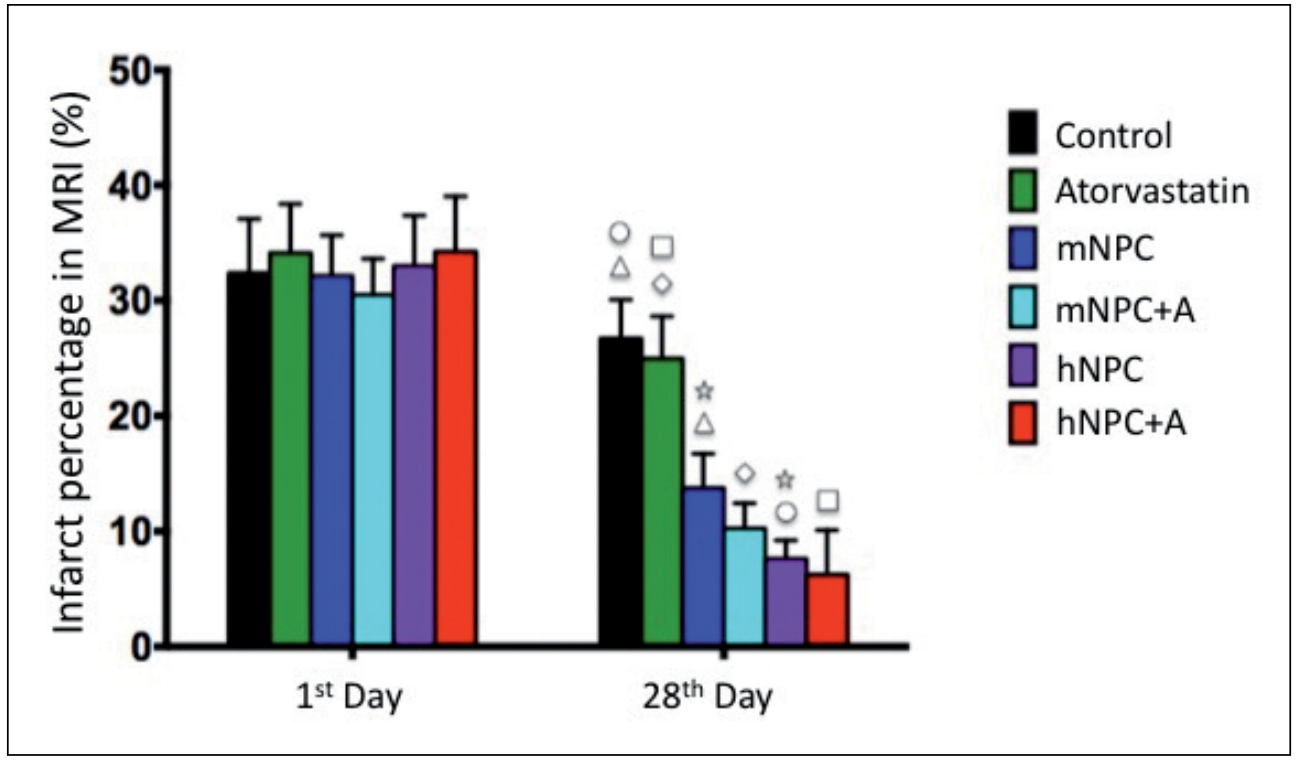

Figure 3: Graphic showing the infarct area ratio in the cranial MRls obtained 1 and 28 days after stroke. The data show infarct ratios, standard error, and statistical analysis $(\mathrm{n}=8)(\triangle \mathrm{\diamond} \square: \mathrm{p}<0.0001$, tr: $p=0.003)$.

(mNPC: Mouse Neural Progenitor Cell, mNPC+A: Mouse Neural Progenitor Cell and oral atorvastatin treatment, hNPC: Human Neural Progenitor Cell,

hNPC+A: Human Neural Progenitor Cell and oral atorvastatin treatment). 
showed improved rotarod test scores from the $14^{\text {th }}$ day until the end of the study (Table III, Figure 5).

Seven days after ischemia, rats that received mNPC achieved significantly higher cylinder test scores compared to the control rats until the end of the study. Fourteen days after ischemia, the rats that received hNPC showed significantly better results compared with DMEM injected control rats until the end of the study. On the last day of the study ( $28^{\text {th }}$ day), the rats treated with hNPC showed significantly better results compared with the rats treated with $\mathrm{mNPC}$, and the rats treated with $\mathrm{MNPC}$ and oral atorvastatin showed significantly better results compared with the rats treated with only mNPC (Table IV, Figure 6).

\section{Immunofluorescent Staining}

In our study, we aimed to show the effect of stem cell therapy on CD5+ T-lymphocytes, and CD5 staining was therefore used for the indirect detection of inflammatory response. CD5 levels were significantly increased in the ischemic hemisphere of mNPC-transplanted rats $(\mathrm{p}=0.038)$, and $\mathrm{mNPC}+\mathrm{A}$-treated rats $(p<0.0001)$ compared with rats injected with DMEM. CD5 levels were also higher in the ischemic hemisphere of $\mathrm{mNPC}+\mathrm{A}$-treated rats compared to $\mathrm{mNPC}$-treated rats but there was no statistical significance (Table V, Figure 7).

We used CD11b staining to detect the microglia levels in the infarct zone to obtain an idea about the apoptosis rate. $\mathrm{CD} 11 \mathrm{~b}+$ levels in the infarct area were significantly reduced both in the mNPC-transplanted rats $(p=0.023)$ and hNPCtransplanted rats $(p=0.001)$ compared to the rats injected with DMEM. There was no significant difference between mNPCtransplanted rats and hNPC-transplanted rats regarding the levels of CD11b. Addition of atorvastatin to the treatment did not lead to any significant difference (Table V, Figure 7).

Table II: Adhesive Removal Test Results (seconds)

\begin{tabular}{|c|c|c|c|c|c|c|}
\hline & $\begin{array}{l}\text { Before } \\
\text { Stroke }\end{array}$ & $1^{\text {st }}$ Day & $7^{\text {th }}$ Day & $14^{\text {th }}$ Day & $21^{\text {st }}$ Day & $28^{\text {th }}$ Day \\
\hline $\begin{array}{l}\text { Control }(\mathbf{n}=\mathbf{8}) \\
\text { Mean } \pm \text { SE Median }\end{array}$ & $\begin{array}{c}6.75+2.12 \\
6.50\end{array}$ & $\begin{array}{c}114.38+5.55 \\
115.50\end{array}$ & $\begin{array}{c}102.38+6.30 \\
101.50\end{array}$ & $\begin{array}{c}92+5.29 \\
91.50\end{array}$ & $\begin{array}{c}77.50+5.95 \\
76\end{array}$ & $\begin{array}{c}70.88 \pm 5.79 \\
73 \\
\end{array}$ \\
\hline $\begin{array}{l}\text { Atorvastatin }(\mathbf{n}=\mathbf{8}) \\
\text { Mean } \pm \text { SE Median }\end{array}$ & $\begin{array}{c}7.25 \pm 1.28 \\
7.50\end{array}$ & $\begin{array}{c}114.88+5.17 \\
116\end{array}$ & $\begin{array}{c}95+8.21 \\
95\end{array}$ & $\begin{array}{c}74.25+3.91 \\
74.50\end{array}$ & $\begin{array}{c}66.88 \pm 3.94 \\
67\end{array}$ & $\begin{array}{c}64.63+2.92 \\
64.50\end{array}$ \\
\hline $\begin{array}{l}\mathbf{m N P C}+\mathbf{A}(\mathbf{n}=\mathbf{8}) \\
\text { Mean } \pm \text { SE Median }\end{array}$ & $6.88 \pm 1.25$ & $\begin{array}{c}115.63+4.10 \\
116\end{array}$ & $\begin{array}{c}81.3 \pm 6.18 \\
81\end{array}$ & $\begin{array}{c}44.38+3.20 \\
4.50\end{array}$ & $\begin{array}{c}43+2.33 \\
43\end{array}$ & $\begin{array}{c}41.88+4.61 \\
41.50\end{array}$ \\
\hline $\begin{array}{l}\mathbf{h N P C}(\mathbf{n}=\mathbf{8}) \\
\text { Mean } \pm \text { SE Median }\end{array}$ & $7.25 \pm \frac{1}{7} .04$ & $\begin{array}{c}116.38+3.38 \\
117\end{array}$ & $\begin{array}{c}64.88 \pm 4.12 \\
65.6\end{array}$ & $\begin{array}{c}45.50 \pm 5.04 \\
45.50\end{array}$ & $\begin{array}{c}34.50 \pm 4.24 \\
33.50\end{array}$ & $\begin{array}{c}33.75 \pm 3.06 \\
33\end{array}$ \\
\hline
\end{tabular}

Table III: Rotarod Test Results

\begin{tabular}{|c|c|c|c|c|c|}
\hline & $1^{\text {st }}$ Day & $7^{\text {th }}$ Day & $14^{\text {th }}$ Day & $21^{\text {st }}$ Day & $28^{\text {th }}$ Day \\
\hline $\begin{array}{l}\mathbf{m N P C}(\mathbf{n}=\mathbf{8}) \\
\text { Mean } \pm \text { SE Median }\end{array}$ & $\begin{array}{c}29.38 \pm 5.01 \\
27.50\end{array}$ & $\begin{array}{c}34.25 \pm 5.99 \\
34.50\end{array}$ & $\begin{array}{c}42.63 \pm 6.61 \\
44\end{array}$ & $\begin{array}{c}45.38+18.86 \\
53\end{array}$ & $\begin{array}{c}54+7.35 \\
54.50\end{array}$ \\
\hline $\begin{array}{l}\mathbf{m N P C}+\mathbf{A}(\mathbf{n}=\mathbf{8}) \\
\text { Mean+SE Median }\end{array}$ & $\begin{array}{c}29.88 \pm 2.59 \\
30\end{array}$ & $\begin{array}{c}41.62 \pm 3.34 \\
42\end{array}$ & $\begin{array}{c}51 \pm 3.42 \\
50\end{array}$ & $\begin{array}{c}57.63 \pm 3.89 \\
59.50\end{array}$ & $\frac{60 \pm 4.44}{60}$ \\
\hline $\begin{array}{l}\text { hNPC }(\mathbf{n}=\mathbf{8}) \\
\text { Mean } \pm \text { SE Median }\end{array}$ & $\begin{array}{c}30 \pm 2.98 \\
29.50\end{array}$ & $\begin{array}{c}42.88 \pm 3.18 \\
42.50\end{array}$ & $\begin{array}{c}51.88 \pm 3.60 \\
50\end{array}$ & $\begin{array}{c}58.50 \pm 4.17 \\
59.50\end{array}$ & $\begin{array}{c}62.13 \pm 4.76 \\
62.50\end{array}$ \\
\hline
\end{tabular}



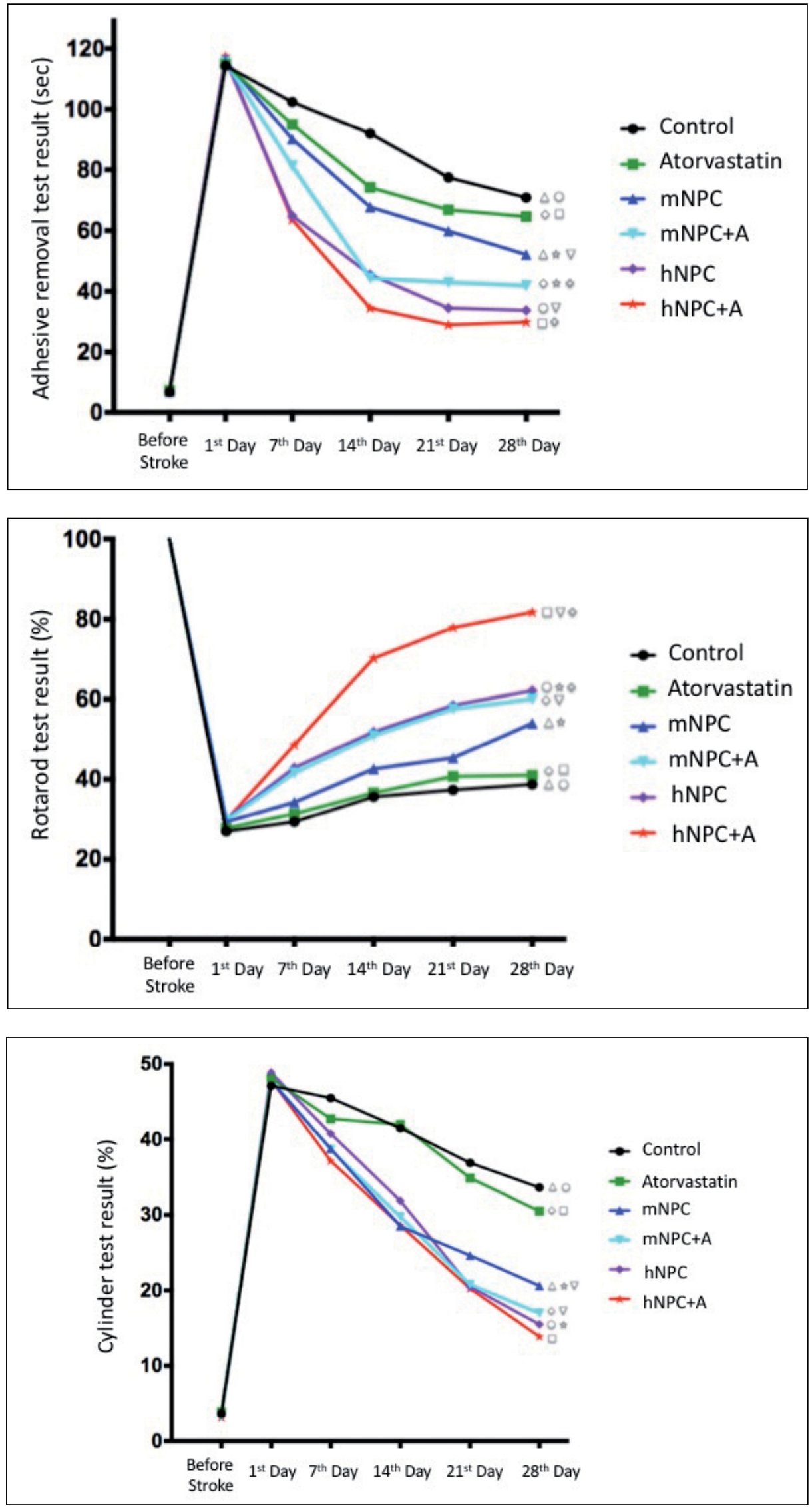

Figure 4: Adhesive removal test results from subjects before stroke and on days $1,7,14,21$, and 28 after the stroke $(n=8)(\triangle \square \diamond 0 \backsim \nabla \omega: p<0.0001)$. (mNPC: Mouse Neural Progenitor Cell, mNPC+A: Mouse Neural Progenitor Cell and oral atorvastatin treatment, hNPC: Human Neural Progenitor Cell, hNPC+A: Human Neural Progenitor Cell and oral atorvastatin treatment).

Figure 5: Rotarod test results from subjects on days $1,7,14,21$, and 28 after stroke $(\mathrm{n}=8)$

$(\triangle O \diamond \square \nabla \backsim: p<0.0001$, 衴: $\mathrm{p}=0.033)$. (mNPC: Mouse Neural Progenitor Cell, mNPC+A: Mouse Neural Progenitor Cell and oral atorvastatin treatment, hNPC: Human Neural Progenitor Cell, hNPC+A: Human Neural Progenitor Cell and oral atorvastatin treatment).

Figure 6: Cylinder test results from subjects before stroke and on days $1,7,14,21$, and 28 after the stroke $(n=8)(\triangle O \diamond \square: p<0.0001$, 放: $p=0.001$, $\nabla: p=0.043)$. (mNPC: Mouse Neural Progenitor Cell, mNPC+A: Mouse Neural Progenitor Cell and oral atorvastatin treatment, hNPC: Human Neural Progenitor Cell, hNPC+A: Human Neural Progenitor Cell and oral atorvastatin treatment). 
We used GFAP staining to detect the rate of gliosis and transformation to astrocytes. The level of GFAP staining in the ischemic hemisphere was significantly increased in mNPC-transplanted rats $(p=0.002)$ and hNPC-transplanted rats $(p<0.0001)$ compared to rats injected with DMEM. Also, GFAP staining in the ischemic hemisphere was significantly increased in the hNPC-transplanted rats compared to mNPC-transplanted rats $(p<0.0001)$. Addition of oral atorvastatin treatment to the hNPC-transplanted rats and mNPC-transplanted rats increased the GFAP staining in the ischemic hemisphere of the hNPC+A-treated rats compared to the hNPC-transplanted rats but there was no statistical significance. It also did not affect GFAP levels in the mNPC+Atreated rats compared to the mNPC-transplanted rats (Table V, Figure 7).

We aimed to observe the T-lymphocyte response via natural killer cells by using antibodies to Granzyme B and CD8a. Spleen tissue was used as a positive control to detect if the antibodies were working. Despite determination of the appropriate dilutions, there was no staining in any of the animals (Table V, Figure 7).

\section{DISCUSSION}

Neuroprotective and neuroregenerative properties of more than a thousand therapeutic agents have been tried on animals but only a few of them could be used in clinical trials (23). The satisfactory results of stem cell research in animal stroke models have therefore provided a new horizon for developing a new method of treatment in stroke (20).

Stem cells provide functional improvement in ischemic brain injury by angiogenesis, immunomodulation, neurotrophic support, and differentiation of neural tissue (17). In previous studies, it has been shown that mNPCs and hNPCs had significant positive effects on functional recovery after stroke $(6,12,25)$. However, there have been no studies comparing mNPC and hNPC treatments in a stroke model so far. Our present study demonstrated that transplantation of mNPCs and hNPCs into the ischemic rat brain reduced infarct volume in MRls and improved neurobehavioral outcomes compared to DMEM injected animals.

One of the main problems in stem cell therapy is that more than $80 \%$ of transplanted stem cells die within 3 days after transplantation in ischemic organs $(21,32)$. Therefore, it is crucial to improve stem cell viability in vivo. Atorvastatin is a hydroxymethylglutaryl-CoA (HMG-CoA) reductase inhibitor which has anti-inflammatory, antioxidant and neuroprotective effects by increasing VEGF and brain-derived neurotrophic factor (BDNF) levels in the brain, increasing eNOS levels in the platelets and inhibiting platelet activation, which can improve the niche of stem cells in the ischemic brain.

Table IV: Cylinder Test Results (\%)

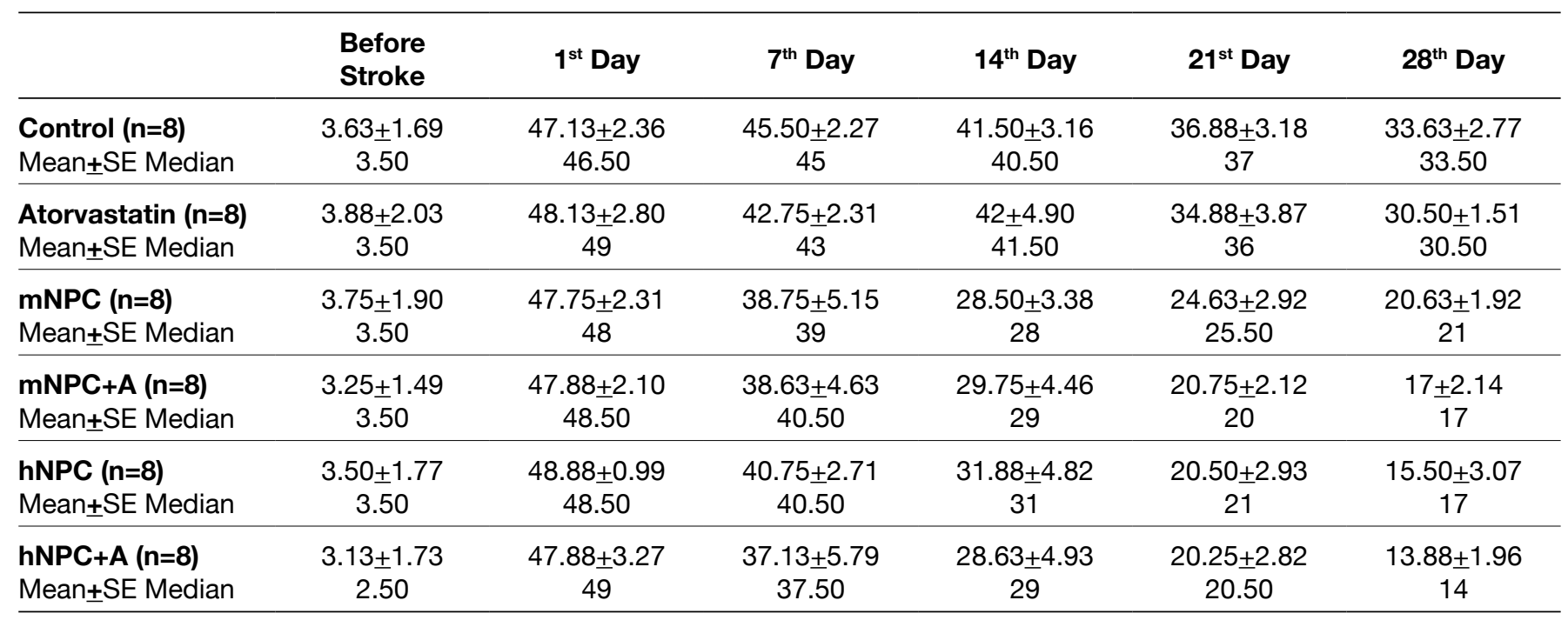

Table V: Immunofluorescence Staining Results

\begin{tabular}{lcccccc}
\hline & Control & Atorvastatin & mNPC & mNPC+A & hNPC & hNPC+A \\
\hline CD5 & + & + & +++ & ++++ & ++ & + \\
\hline CD11b & +++ & + & ++ & ++ & + & + \\
\hline GFAP & - & + & ++ & ++ & +++ & ++++ \\
\hline Granzyme B CD8a & - & - & - & - & - & - \\
\hline
\end{tabular}

-: No staining, +: Very little staining, ++: Little staining, +++: Staining, ++++: More staining. 
Tu et al. and Yriänheikki et al. showed that atorvastatin provided significant functional recovery compared to the control group in a focal cerebral ischemia model $(34,38)$. We therefore decided to add oral atorvastatin treatment to produce a more suitable niche for stem cells in mNPC-transplanted rats' and hNPC-transplanted rats' brains. Rats treated with $\mathrm{mNPC}+\mathrm{A}$ and rats treated with $\mathrm{hNPC}+\mathrm{A}$ had smaller infarct volumes on $\mathrm{MRI}$ and better neurobehavioral outcomes compared to rats treated with only mNPC or hNPC but there was no statistical significance.

$\mathrm{Li}$ et al. compared the route (intra-arterial, intravenous or intracerebral) of transplantation of stem cells in a stroke model. According to data obtained from this study, the intravenous route is safe and easy to apply but the success rate is low because of delayed migration to ischemic tissue and attachment to peripheral organs. Despite the invasiveness and side effects such as embolism and epileptic seizure, intra-arterial and intracerebral transplantation are more effective than the intravenous route because great amounts of stem cells can reach the ischemic tissue faster (19). The intracerebral transplantation technique was used in our study and we did not encounter any side effects such as seizure and embolism. The effectiveness of stem cells was satisfactory and no mortality was observed.

CD5+ lymphocytes have anti-inflammatory effects through IL10 and they provide neuroprotection (11). However, there is only one study showing the interaction of stem cells with the
CD5+ lymphocytes in the infarct area. Jablonska et al. found no CD5 staining in the infarct area of rat brains after stem cell administration (15). In our study, CD5 staining was more prominent in the stem cell therapy groups (mNPC, hNPC) than the control group. It is possible to say that NPCs have antiinflammatory effects through CD5+ cells in the infarct area. The addition of atorvastatin to stem cell therapy led to more CD5 staining in the $\mathrm{mNPC}+\mathrm{A}$ group than the mNPC group with no significant statistical difference.

Capone et al. found that NPCs caused accumulation of CD11b+ myeloid cells to increase neuroprotective effects in the infarct area of mouse brains (3). In a study conducted by Bacigaluppi et al., NPC treatment increased neuronal survival and locomotor function, although there was reduction of CD11b staining (microglia amount) in the cerebral ischemia model in mice (2). mNPCs were transplanted to the cerebral infarct area of the rat and a negative correlation between microglial activation and neuronal survival was found by Hicks et al.(13). As a result of these studies; microglia have dual roles (pro-inflammatory and anti-inflammatory) in stroke depending on their activation types and functional phenotypes (9). In our study, there was a statistically significant reduction of CD11b staining after NPC transplantation compared to the control group. Although mNPC-transplanted rats had more CD11b staining than hNPC-transplanted rats, hNPC-transplanted rats had better functional recovery; suggesting that hNPC transplantation caused more microglia deactivation resulting

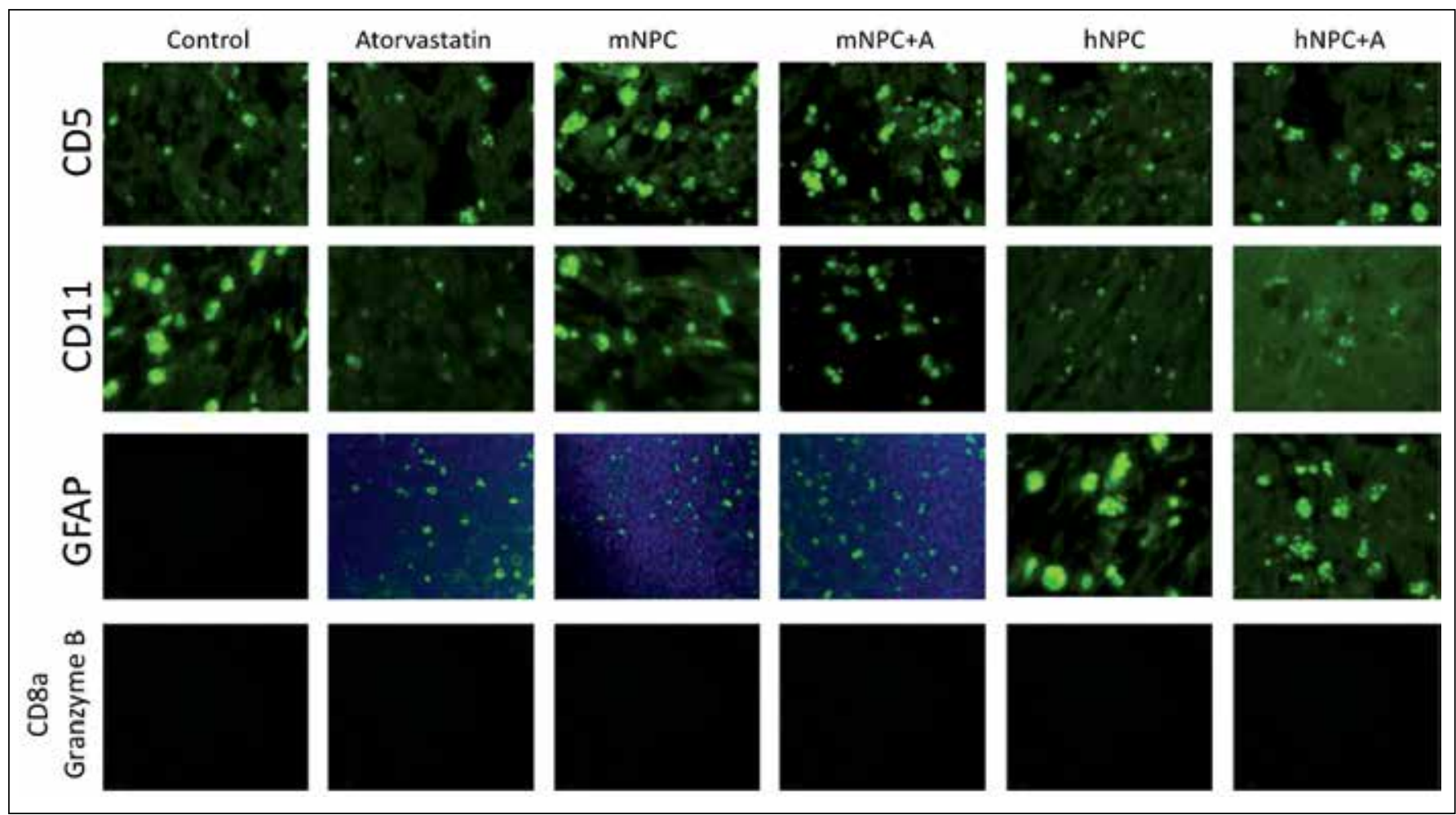

Figure 7: CD5, CD11b, GFAP, CD8a and granzyme B stainings. (GFAP: Glial Fibrillary Acidic Protein, mNPC: Mouse Neural Progenitor Cell, mNPC+A: Mouse Neural Progenitor Cell and oral atorvastatin treatment, hNPC: Human Neural Progenitor Cell, hNPC+A: Human Neural Progenitor Cell and oral atorvastatin treatment). 
in more anti-inflammatory response. The addition of oral atorvastatin treatment to stem cell transplantation did not lead to any significant changes in CD11b staining. In addition, locomotor functional recovery and lower rate of CD11b staining after stem cell transplantation suggested that proinflammatory effects of microglia are on the front burner in the pathophysiology of stroke.

Astrocytes promote the proliferation and survival of developing neurons. They also initiate the formation of synapses and stabilize synaptic activity $(27,29)$. Tang et al. and Yuan et al. observed that most of the transplanted NPCs were transformed into GFAP + astrocytes in ischemic stroke models $(33,39)$. In a study conducted by Takano et al., functional recovery and neuronal regeneration were decreased by glial scar formation in the subacute phase (31). As a result, the dual effect of GFAP+ cells is not clear in stroke (27). In our study, similar to Tang et al. and Yuan et al.'s studies, more GFAP staining was found in stem cell transplanted ischemic rat brains than DMEM injected rat brains. Significant functional recovery and more GFAP staining in the NPC transplanted groups suggested that formation of astrocytes had positive effects in the acute phase of stroke.

The central nervous system contains small amount of cytotoxic T-lymphocytes (CTL). CD8+ CTLs infiltrate the central nervous system in the ischemic brain, in Alzheimer's disease, and after trauma. However, the role of these cells after cerebral ischemia-reperfusion injury is not fully understood $(14,26)$. In two different studies in rat and human autopsies, Chaitanya et al. found increased staining of CD8a and granzyme B in brain tissue, and stated that granzyme $B$ secretion from CTLs had increased apoptosis in brain tissue $(4,5)$. In our study, no CD8a or granzyme B staining were detected in ischemic rat brains. So, unlike Chaitanya et al.'s study, we think CTLs have no effect on the pathophysiology of cerebral ischemia, and stem cell transplantation does not change the amount and function of CTLs.

The commonly used immunosuppressant, cyclosporine $A$, restricts the immune response and facilitates transplant survival, and also has neuroprotective effects (reduces cell death and preserves neuron integrity) (24). All animals were treated daily with cyclosporine A to prevent the development of a transplant-induced inflammatory response in our study. Since cyclosporine A was applied to all animals, its probable positive or negative effects should not be considered. This study did not focus on the effects of cyclosporine $A$ in the groups, and it would have some unpredicted effects on the experiment.

\section{- CONCLUSION}

To our knowledge, this is the first report that compares mNPC and hNPC, and demonstrates the effect of atorvastatin on stem cells in a stroke model. Our study demonstrated that NPCs are useful options for the treatment of focal cerebral ischemia. The addition of atorvastatin showed positive effects on stem cells; however most of them were not statistically significant. Atorvastatin can be a promising option to promote the efficacy of NPCs. Further studies with more animals in each group are needed.
NPC transplantation (especially hNPC) appears feasible. This strategy of supporting stem cells with atorvastatin may present a safe approach for improving the beneficial effects of stem cell therapy for cerebral ischemia. However, the variables of regimen need optimization for further clinical studies. These mechanisms of functional recovery after stem cell therapy need to be evaluated. Further studies are needed to show synaptic connections and functional neuroradiological recovery after stem cell and atorvastatin treatment in the stroke model.

\section{ACKNOWLEDGMENT}

We thank Ahmet Cingöz for assistance with NPC culture. This work was supported by Istanbul University Scientific Research Projects under Grant 50529.

\section{REFERENCES}

1. Auriel E, Bornstein NM: Neuroprotection in acute ischemic stroke-current status. J Cell Mol Med 14: 2200-2202, 2010

2. Bacigaluppi M, Pluchino S, Jametti LP, Kilic E, Kilic U, Salani G, Brambilla E, West MJ, Comi G, Martino G, Hermann DM: Delayed post-ischaemic neuroprotection following systemic neural stem cell transplantation involves multiple mechanisms. Brain 132:2239-2251, 2009

3. Capone C, Frigerio S, Fumagalli S, Gelati M, Principato MC, Storini C, Montinaro M, Kraftsik R, De Curtis M, Parati E, De Simoni MG: Neurosphere-derived cells exert a neuroprotective action by changing the ischemic microenvironment. PLoS ONE 2(4): e373, 2007

4. Chaitanya GV, Eeka P, Munker R, Alexander JS, Babu PP: Role of cytotoxic protease granzyme-b in neuronal degeneration during human stroke. Brain Pathol 21: 16-30, 2011

5. Chaitanya GV, Schwaninger M, Alexander JS, Babu PP: Granzyme-b is involved in mediating post-ischemic neuronal death during focal cerebral ischemia in rat model. Neuroscience 165: 1203-1216, 2010

6. Chang DJ, Oh SH, Lee N, Choi C, Jeon I, Kim HS, Shin $\mathrm{DA}$, Lee SE, Kim D, Song J: Contralaterally transplanted human embryonic stem cell-derived neural precursor cells (ENStem-A) migrate and improve brain functions in strokedamaged rats. Exp Mol Med 45: e53, 2013

7. Chen J, Zhang ZG, Li Y, Wang Y, Wang L, Jiang H, Zhang C, Lu M, Katakowski M, Feldkamp CS, Chopp M: Statins induce angiogenesis, neurogenesis, and synaptogenesis after stroke. Ann Neurol 53: 743-751, 2003

8. Cimino M, Balduini W, Carloni S, Gelosa P, Guerrini U, Tremoli E, Sironi L: Neuroprotective effect of simvastatin in stroke: A comparison between adult and neonatal rat models of cerebral ischemia. Neurotoxicology 26: 929-933, 2005

9. Daadi MM, Davis AS, Arac A, Li Z, Maag AL, Bhatnagar R, Jiang K, Sun G, Wu JC, Steinberg GK: Human neural stem cell grafts modify microglial response and enhance axonal sprouting in neonatal hypoxic-ischemic brain injury. Stroke 41: 516-523, 2010

10. Endres M, Laufs U, Huang Z, Nakamura T, Huang P, Moskowitz MA, Liao JK: Stroke protection by 3-hydroxy-3-methylglutaryl (HMG)-CoA reductase inhibitors mediated by endothelial nitric oxide synthase. Proc Natl Acad Sci 95: 8880-8885, 1998 
11. Frangogiannis NG, Youker KA, Rossen RD, Gwechenberger $\mathrm{M}$, Lindsey $\mathrm{MH}$, Mendoza LH, Michael LH, Ballantyne CM, Smith CW, Entman ML: Cytokines and the microcirculation in ischemia and reperfusion. J Mol Cell Cardiol 30:2567-2576, 1998

12. Hicks AU, Lappalainen RS, Narkilahti S, Suuronen R, Corbett D, Sivenius J, Hovatta O, Jolkkonen J: Transplantation of human embryonic stem cell-derived neural precursor cells and enriched environment after cortical stroke in rats: Cell survival and functional recovery. Eur J Neurosci 29:562-574, 2009

13. Hicks AU, MacLellan CL, Chernenko GA, Corbett D: Longterm assessment of enriched housing and subventricular zone derived cell transplantation after focal ischemia in rats. Brain Res 1231:103-112, 2008

14. Hurn PD, Subramanian S, Parker SM, Afentoulis ME, Kaler LJ, Vandenbark AA, Offner H: T- and B-cell-deficient mice with experimental stroke have reduced lesion size and inflammation. J Cereb Blood Flow Metab 27:1798-1805, 2007

15. Jablonska A, Kozlowska H, Markiewicz I, Domanska-Janik $\mathrm{K}$, Lukomska B: Transplantation of neural stem cells derived from human cord blood to the brain of adult and neonatal rats. Acta Neurobiol Exp Wars 70:337-350, 2010

16. Jensen MB, Yan H, Krishnaney-Davison R, Al Sawaf A, Zhang SC: Survival and differentiation of transplanted neural stem cells derived from human induced pluripotent stem cells in a rat stroke model. J Stroke Cerebrovasc Dis 22:304-308, 2013

17. Kim HS, Choi SM, Yang W, Kim DS, Lee DR, Cho SR, Kim DW: PSA-NCAM(+) Neural Precursor cells from human embryonic stem cells promote neural tissue integrity and behavioral performance in a rat stroke model. Stem Cell Rev 10(6):761771,2014

18. Krishnamurthi RV, Moran AE, Feigin VL, Barker-Collo S, Norrving B, Mensah GA, Taylor S, Naghavi M, Forouzanfar $\mathrm{MH}$, Nguyen G, Johnson CO, Vos T, Murray CJL, Roth GA, Group for the G 2013 SPE: Stroke prevalence, mortality and disability-adjusted life years in adults aged 20-64 years in 1990-2013: Data from the Global Burden of Disease 2013 Study. Neuroepidemiology 45: 190-202, 2015

19. Li L, Jiang Q, Ding G, Zhang L, Zhang ZG, Li Q, Panda S, Lu M, Ewing JR, Chopp M: Effects of administration route on migration and distribution of neural progenitor cells transplanted into rats with focal cerebral ischemia, an MRI study. J Cereb Blood Flow Metab 30: 653-662, 2010

20. Mir O, Savitz SI: Stem cell therapy in stroke treatment: Is it a viable option? Expert Rev Neurother 13: 119-121, 2013

21. Müller-Ehmsen J, Whittaker P, Kloner RA, Dow JS, Sakoda T, Long TI, Laird PW, Kedes L: Survival and development of neonatal rat cardiomyocytes transplanted into adult myocardium. J Mol Cell Cardiol 34: 107-116, 2002

22. Neumann-Haefelin T, Kastrup A, de Crespigny A, Yenari MA, Ringer T, Sun GH, Moseley ME: Serial MRI after transient focal cerebral ischemia in rats: Dynamics of tissue injury, bloodbrain barrier damage, and edema formation. Stroke 31: 19651972; discussion 1972-1973, 2000

23. O'Collins VE, Macleod MR, Donnan GA, Horky LL, Van Der Worp BH, Howells DW: 1,026 Experimental treatments in acute stroke. Ann Neurol 59: 467-477, 2006

24. Osman MM, Lulic D, Glover L, Stahl CE, Lau T, van Loveren $\mathrm{H}$, Borlongan CV: Cyclosporine-A as a neuroprotective agent against stroke: Its translation from laboratory research to clinical application. Neuropeptides 45: 359-368, 2011
25. Ramos-Cabrer P, Justicia C, Wiedermann D, Hoehn M: Stem cell mediation of functional recovery after stroke in the rat. PLoS ONE 5: 1-11, 2010

26. Robinson Agramonte M, Dorta-Contreras AJ, Lorigados Pedre L: Immune events in central nervous system of early and late onset Alzheimer's disease patients. Rev Neurol 32: 901-904, 2001 (In Spanish)

27. Sanai N, Tramontin AD, Quiñones-Hinojosa A, Barbaro NM, Gupta N, Kunwar S, Lawton MT, McDermott MW, Parsa AT, Manuel-García Verdugo J, Berger MS, Alvarez-Buylla A: Unique astrocyte ribbon in adult human brain contains neural stem cells but lacks chain migration. Nature 427: 740-744, 2004

28. Schallert T, Fleming SM, Leasure JL, Tillerson JL, Bland ST: CNS plasticity and assessment of forelimb sensorimotor outcome in unilateral rat models of stroke, cortical ablation, parkinsonism and spinal cord injury. Neuropharmacology 39 : 777-787, 2000

29. Song $H$, Stevens $C F$, Gage FH: Astroglia induce neurogenesis from adult neural stem cells. Nature 417: 39-44, 2002

30. Takahashi K, Yasuhara T, Shingo T, Muraoka K, Kameda M, Takeuchi A, Yano A, Kurozumi K, Agari T, Miyoshi Y, Kinugasa $\mathrm{K}$, Date I: Embryonic neural stem cells transplanted in middle cerebral artery occlusion model of rats demonstrated potent therapeutic effects, compared to adult neural stem cells. Brain Res 1234: 172-182, 2008

31. Takano T, Oberheim NA, Cotrina ML, Nedergaard $M$ : Astrocytes and ischemic injury. Stroke 40 Suppl 3: S8-S12, 2009

32. Tambara K, Sakakibara Y, Sakaguchi G, Lu F, Premaratne GU, Lin X, Nishimura K, Komeda M: Transplanted skeletal myoblasts can fully replace the infarcted myocardium when they survive in the host in large numbers. Circulation 108 Suppl 1: II259-263, 2003

33. Tang Y, Wang J, Lin X, Wang L, Shao B, Jin K, Wang Y, Yang GY: Neural stem cell protects aged rat brain from ischemiareperfusion injury through neurogenesis and angiogenesis. J Cereb Blood Flow Metab 34: 1138-47, 2014

34. Tu Q, Cao H, Zhong W, Ding B, Tang X: Atorvastatin protects against cerebral ischemia/reperfusion injury through antiinflammatory and antioxidant effects. Neural Regen Res 9: 268-275, 2014

35. Uluc K, Miranpuri A, Kujoth GC, Akture E, Baskaya MK: Focal cerebral ischemia model by endovascular suture occlusion of the middle cerebral artery in the rat. J Vis Exp 48: 1978, 2011

36. Unal OF, Dosoglu M, Diler AS, Hamamcioglu MK, Bayindir C: Lipid peroxidation in focal cerebral ischaemia and reperfusion (Part I). Turk Neurosurg 2: 117-123, 1992

37. Unal OF, Dosoglu M, Diler AS, Hamamcioglu MK, Bayindir C: Effects of deferoxamine of lipid peroxidation in focal cerebral ischaemia and reperfusion (Part II). Turk Neurosurg 2: 124128, 1992

38. Yrjanheikki J, Koistinaho J, Kettunen M, Kauppinen RA, Appel K, Hull M, Fiebich BL: Long-term protective effect of atorvastatin in permanent focal cerebral ischemia. Brain Res 1052: 174-179, 2005

39. Yuan T, Liao W, Feng NH, Lou YL, Niu X, Zhang AJ, Wang $Y$, Deng ZF: Human induced pluripotent stem cell-derived neural stem cells survive, migrate, differentiate, and improve neurologic function in a rat model of middle cerebral artery occlusion. Stem Cell Res Ther 4: 73, 2013 